\title{
Research on Flipped Classroom Teaching Model Based on College Human Resource Management Course
}

\author{
Yuan $\mathrm{FU}^{1,}$, Fashuang $\mathrm{HUANG}^{2, \mathrm{~b}}$ \\ ${ }^{1}$ Wuhan Business University, Wuhan,430056, China \\ ${ }^{2}$ Wuhan Business University, Wuhan,430056, China \\ aemail:627356365@qq.com, bemail: 49241462@qq.com
}

Key words: Human Resource Management; Flipped Classroom; Teaching Model

\begin{abstract}
Human resource management is a course with high applicability and operability. The existing research has widely and deeply discussed the application of the traditional teaching method in human resource management course teaching, and flipped classroom teaching method is a new teaching method developed abroad in recent years with little research. The author has thought that flipped classroom teaching method can be highly applied in human resource management course. So this paper conducted research on the application of flipped classroom teaching method in human resource management course with the purpose of improving teaching quality and teaching effects of the course.
\end{abstract}

\section{Introduction}

Flipped classroom, as a kind of brand-new teaching mode, reversely organizes the traditional teaching activities both inside and outside classroom, in order to realize the improvement of teaching quality. [1]The application of flipped classroom is beneficial to solve the current problem of human resource management (HRM) course teaching and provide a new view to the course reformation. [2] Therefore, to increase the teaching quality of management course, currently HRM teaching is supposed to make further exploration from pre-class instruction, classroom instruction and post-class instruction three levels, constructing a set of HRM teaching model based on flipped classroom.

\section{Flipped Classroom}

Flipped Classroom originates from the year of 2007 when an American chemistry teacher in middle school recorded video to absent students for autonomous study at home. In our nation, the research time of flipped classroom is not long with the earliest research started in 2012 from the research results of CNKI[3] [4] [5]; from the perspective of research content, the national research mostly has focused on science and engineering disciplines except for English, Politics and other subjects. Qiliang Zhang through the analysis of the disadvantages of traditional teaching (Face to Face) and network teaching (E-Learning), designed a mixed teaching model based on flipped classroom and used 'embedded system software design' as the experimental course to examine and analyze the application effect of this model. Yi Chen designed a teaching plan based on flipped classroom with the example of 'computer application basis' course and made analysis of the study effect. [6]And Yanjiang Lin according to learning effect pyramid theory and the content of flipped classroom, put forward a new way of flipped classroom and analyzed the application of such a new way combined with the teaching practice of 'electronic albums production'. [7] Although liberal art disciplines also are involved in the research of flipped classroom, it is relatively a small proportion.

The flipped classroom teaching model is a new model that turns the traditional teaching with the fixed form in which teachers teach during class and students do homework after class into another form in which students search relative instructional resources and learn outside classroom and do school work in class and when problems occur, they can ask and discuss with teachers or classmates to solve them together. 


\section{Necessity of Applying Flipped Classroom in HRM}

\section{A. Existing teaching problems in HRM}

Based on the characteristics of manpower demand in HRM, many national universities put forward the target of cultivating talents with abundant theoretical knowledge, strong practical skill and good comprehensive quality and have made a plenty of teaching reformations which are not perfect enough. These drawbacks are as follows: firstly, emphasize teaching. Teachers are dominant in the classroom and teach students in a 'spoon-fed' way according to what teachers prepared before class, meanwhile, students listen the class in a passive way. Teachers put emphasis on knowledge teaching and students lack positive participation in class teaching, which lead to low autonomy and motivation of students. [8]The theoretical knowledge teachers teach students is too abstract to make students be interested in. The students only feel empty and bored. Even if teachers used some cases for illustration, it is still easy to make students feel abstract if these cases are not familiar to them, which still can't promote students' interest. Secondly, take practice for granted. Such a 'spoon-fed' way condenses the interaction between teachers and students like case analysis and question discussion, which can't give students enough enlightenment and constrain students' thought innovation and ability improvement. Thirdly, in the present internet era when the multimedia instant communication widely spreads, the students after 1990s favor study methods based on internet, however, the traditional teaching ignores the advantage of internet resources with limited teaching content and obsolete teaching means which also can't meet the requirements of national education informatization.

\section{B. Lacking Enough Research Attention to HRM Teaching Based on flipped classroom}

In recent years, there have already been many researches that make the idea of flipped classroom penetrate into HRM teaching such as engagement learning, MOOC, etc. These researches include: Qiping Wang and Jun Wang claimed that taking the advantage of flipped classroom in HRM teaching would be beneficial to the development of learners' applicability; Jianli Gao and Yirong Gao proposed that bringing engagement learning into HRM course could deepen students' understanding of theories, improve their ability to solve practical problems and strengthen their cooperative awareness; Fei Fan found that the teaching model of combining MOOC and HRM professional skills course in vocational colleges could help students accomplish study more positively and effectively; Peng Liu put forward based on theory of constructivism, the reformation and design of teaching goals, teaching methods and evaluation means and so on would benefit students in their capability of transforming knowledge into ability and enhance the teaching effects. [9]So it is obvious that concept of flipped classroom has already become the new trend of HRM teaching research, but the researches on the specific application steps of comprehensively and systematically designing flipped classroom based on HRM teaching course is few.

In conclusion, how to solve the existing problem in HRM teaching and how to improve students' ability of theoretical knowledge application, practical operation, autonomous study and problem-solving, making the students in HRM major meet the requirements of market are the significant problems HRM educators face now. And flipped classroom can afford a new breakthrough to solve these problems with its idea of positive learning, personalization and engagement learning which are the right points of solution.

\section{Construction of HRM Teaching Model Based on Flipped Classroom}

\section{A. Integrated HRM Teaching Model Based on Flipped Classroom}

The appearance of 'flipped classroom' provides a new view to HRM teaching reformation. After taking the advantages of flipped classroom and connected learning effect pyramid theory, this paper constructed HRM teaching model framework as Figure 1. 


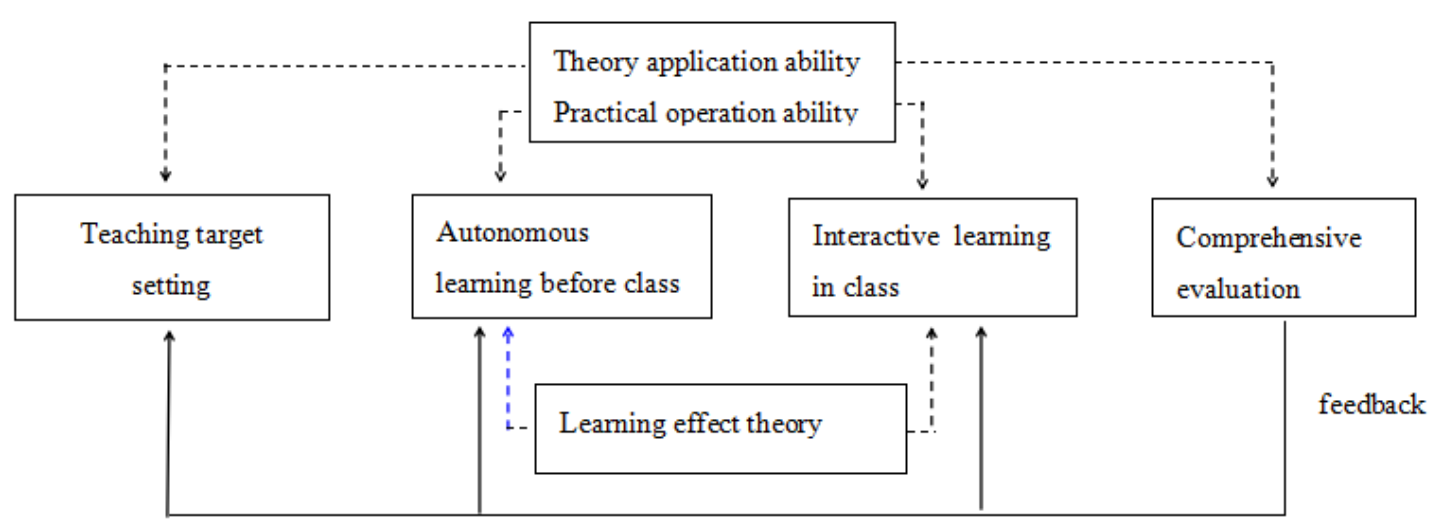

Figure 1: Integrated HRM teaching model based on flipped classroom

HRM teaching model consists of teaching target setting, autonomous learning before class, and interactive learning in class and comprehensive evaluation which unfold towards the target of developing the theoretical application ability and practical operation ability of HRM students. Autonomous learning before class and interactive learning in class is the core in traditional flipped teaching. In the past, teachers taught students the fundamental concepts and methods in class, and now students finish this part in their own way before class. And the class time is used for the discussion, communication and evaluation of key points among students and students or students and teachers. Besides, the application of learning effect pyramid theory into the teaching before and in class is a good way to improve flipped classroom teaching effect. Teaching effect will be given a feedback through periodical and conclusive comprehensive evaluation and it will be the foundation of adjusting teaching target and improving flipped classroom teaching method.

\section{B. Detailed Model Design of HRM Teaching Based on Flipped Classroom}

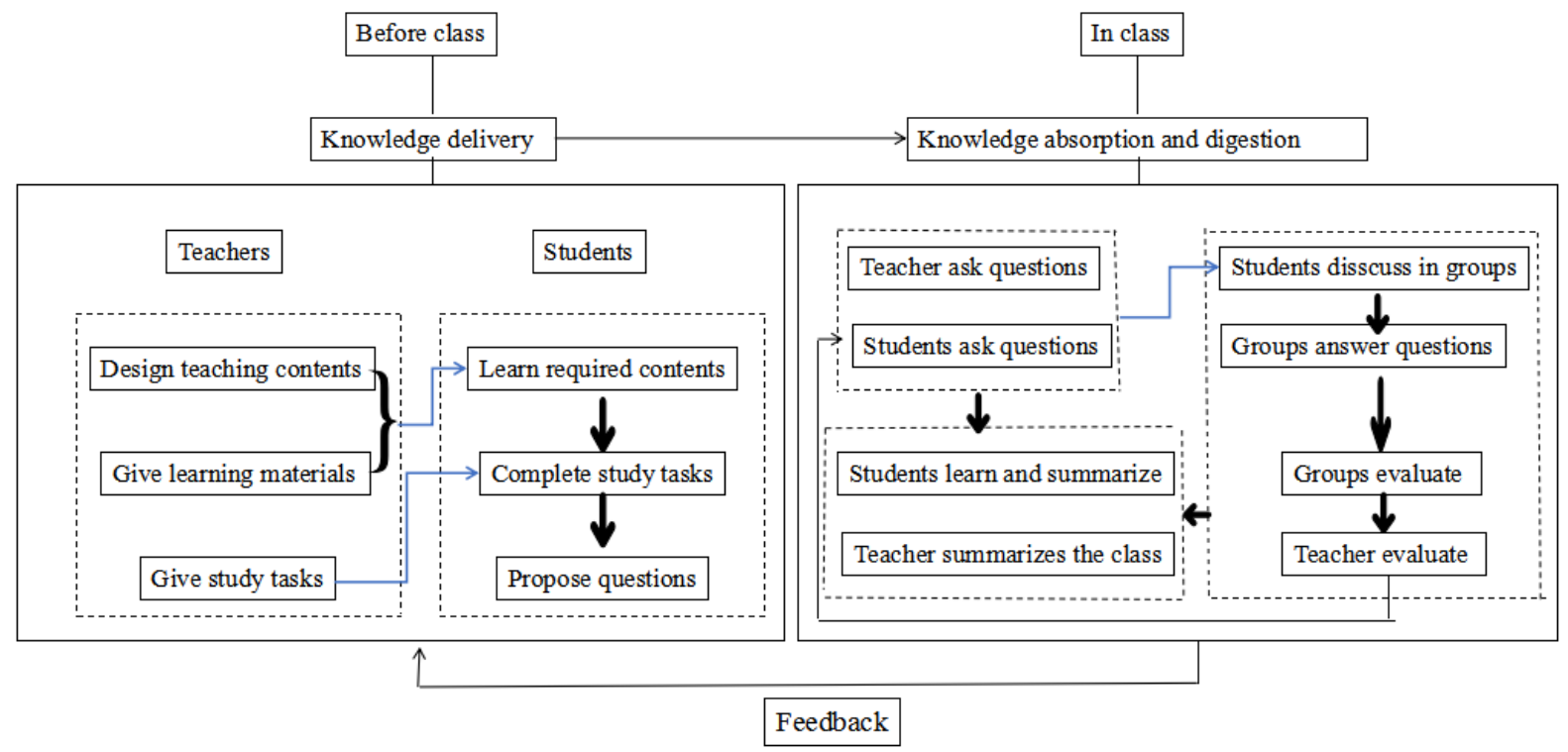

Figure 2: HRM teaching model based on flipped classroom

a. Knowledge Delivery Period before Class

At first, teachers provide students the videos, exercises and learning materials according to which students accomplish autonomous learning. To ensure the learning quality, there are two points deserving attention: firstly, teaching videos are important media in flipped classroom. Whether teachers can record high-quality teaching videos is the first step of teaching reformation and also is the key point of guaranteeing autonomous learning effect. But it is the right skill that most our teachers are supposed to develop. Secondly, the questions teachers proposed before class should present the teaching importance and difficult and follow tightly the discipline frontier. At the same time, teachers should take students' learning ability and knowledge level into consideration to control the difficulty and quantity of questions, encouraging students to positively participate and learning interest to prepare for the next step, that is the classroom participatory cooperation study. 


\section{b. Classroom Teaching Activity Period}

In this process, teachers fully arouse students' logical thinking, helping students optimize former knowledge structure and internalize the knowledge and then transforming the theories into practical application ability. First of all, teachers simply review the fundamental knowledge and answer questions of exercises in autonomous learning. Then they ask students to answer these questions and let students choose interested questions freely to make preparation for the next step. Next, students start cooperative learning and group discussion. Teachers will arrange students with the same questions in one group with 4-6 people, simultaneously, give tasks based on students' willing and ability. And then, students communicate and share their research results with peers. The next step is discussion between group. Teachers use appropriate means like brainstorming and debating to encourage students to speak out their thoughts. And teachers should pay enough attention to the discussion and give necessary guidance. Finally it is the stage of showing results. Students conclude and share what they have discussed just now, may through small competition, exhibition and presentation, etc.

\section{Conclusion}

To meet the talent requirements of human resource industry, college HRM teaching model must be under a reformation to change the current teaching situation of 'emphasizing theories and diminishing practice' and "' 'theories' irrelevance with practice”. Flipped classroom can effectively improve the situation of the traditional teaching in which teaching is separate from learning. But its implementation effect more relies on students' learning autonomy and teachers' teaching methods. This paper based on the concept of flipped classroom, proposed a HRM teaching model based on flipped classroom with the task-oriented pedagogy promoting students' autonomous learning, HR talent demand as foundation and learning effect pyramid theory put into the design of teaching methods. This model provides more opportunities of autonomous learning and practicing and develops students' ability to solve problems, communicate cooperatively and practice effectively.

\section{Acknowledgement}

In this paper, the research was sponsored by Recruitment and Employment bilingual teaching quality project.

\section{References}

[1] Stern H H.Seeing the wood AND the trees: Some thoughts on language teaching analysis. The Second Language Curriculum. 1989

[2] Carter, D.Some propositions about ESP. The ESP Journal . 1983

[3] Dubin F,Olshtain E.Course Design: Developing Program and Materials for language learning. Journal of Women s Health . 1986

[4] Ellis,M.,FJohnson,C.Teaching Business English. Oxford Handbooks for Language Teachers . 1996

[5] Gagne RM.The Conditions of Learning and Theory of Instruction. Journal of Women s Health . 1985

[6] Ziss,Steffen.Strategic R\&D with Spillovers, Collusion and Welfare. The Journal of Industrial Economics . 1994

[7]Elizabeth A Jones,Steven Hoffman,Lynn Melander Moore,Gary Ratcliff,Stacy Tibbetts,Benjamin A.L.Click,III.National Assessment of College Student Learning:Identif-ying college graduates' 'essential skills in writing,speech andlistening,and critical thinking.Final project report. 1995 
[8] Madonna G Constantinea,Gregory M. Anderson,LaVerne A. Berkel,Leon. Caldwell,Shawn O. Utsey.Examining the Cultural Adjustment Experiences of African International College Students:A Qualitative Analysis. International Journal of Educational Research . 2005

[9] M.G.Brock,M.C.Curthoys.The Histroy of the University of Oxford. . 1997 